\title{
TANTANGAN DAN PELUANG PARIWISATA CERDAS : AKOMODASI EKONOMI BERBAGI
}

\author{
Christian Harazaki Mendrofa ${ }^{1}$, Dadang Suganda ${ }^{1}$, Evi Novianti ${ }^{1}$ Awaludin Nugraha $^{2}$ \\ ${ }^{1}$ Sekolah Pasca Sarjana, Universitas Padjadjaran, Jl. Dipatiukur no. 35 \\ ${ }^{2}$ Fakultas Ilmu Budaya, Universitas Padjadjaran, Jl. Dipatiukur no. 35 \\ chris.mendrofa@gmail.com, dadang.suganda@unpad.ac.id, evi.novianti@unpad.ac.id, \\ awaludin.nugraha@unpad.ac.id
}

\begin{abstract}
ABSTRAK
Dalam beberapa tahun ke belakang telah terjadi perkembangan kolaborasi ekonomi berbagi secara pesat menggunakan platform peer to peer. Dalam dunia pariwisata, contoh terbaik yang dapat mewakili perkembangan ini adalah platform rental akomodasi jangka pendek Airbnb. Artikel ini menganalisa pertumbuhan platform Airbnb, inovasi yang digunakan juga alasan wisatawan dan masyarakat pemilik properti menggunakan platform tersebut. Namun dibalik perkembangan platform dan peningkatan ekonomi masyarakat terjadi beberapa permasalahan mulai dari masalah potensi diskriminasi bahkan kriminal yang terjadi dari interaksi yang terjadi di dalam ruang umum akomodasi tersebut. Penelitian ini merupakan penelitian kualitatif dengan metode deskriptif. Data diperoleh melalui studi literatur, wawancara dan pengamatan langsung. Hasil penelitian menunjukan bahwa jaminan platform berupa garansi perbaikan kerusakan rumah mampu meyakinkan tuan rumah untuk menyewakan akomodasinya dan juga bantuan Big Data dalam pencarian konsumen mempercepat keputusan pembelian wisatawan.
\end{abstract}

Kata kunci; pariwisata cerdas, akomodasi, ekonomi berbagi

\section{CHALLENGE AND OPPORTUNITY OF SMART TOURISM : SHARING ECONOMIC ACCOMODATION}

\section{ABSTRACT}

In the pas years has been rapidly collaboration sharing economic development using peer to peer platform. In Tourism, the best example to represent the development is short term accomodation rental Airbnb. This article analyze the growth of Airbnb platform, innovation has been used and the reason member use the platform. But behind the platform development and growth of society economic has been some problem that happen lately, from the hotel as kompetitor, discrimination and also criminal problem because of the interaction in sharing space in the accomodation. This research is qualitative study with descriptive method. The data for this research gathered through literature study, interview and direct observation.. The results showed that Host Guarantee was able to convince the host to rent out the accommodation and also the help of Big Data in the search for consumers to speed up the purchase decision of tourists.

Key words; smart tourism, accomodation, sharing economic

\section{PENDAHULUAN}

Dalam upaya meningkatkan taraf hidup masyarakat, membuka lapangan pekerjaan yang baru salah satu aspek ekonomi yang dapat dibangun dengan mudah dan murah adalah sektor pariwisata. (Ramli : 2016) Namun di balik itu pengembangan pariwisata dapat pula menimbulkan masalah dalam masyarakat seperti masalah lingkungan, sosial dan budaya. Kompleksitas permasalahan menuntut masyarakat untuk menyelesaikan masalah tersebut secara inovatif, efektif, efisien dan mengoptimalkan sumber daya yang ada untuk mampu bersaing di skala nasional maupun internasional, dan mendorong pemerintah dan masyarakat untuk berinovasi dalam memajukan daerahnya.

Inovasi-inovasi yang tercipta untuk menyelesaikan permasalahan kota berdampak positif pada kemajuan pembangunan kota di berbagai bidang. Kota-kota yang menawarkan pelayanan yang maju dan inovatif bagi masyarakatnya ini sering disebut sebagai kota cerdas (Smart City) (Piro, 2014). Konsep kota cerdas tersebut juga dapat diaplikasikan pada bidang pariwisata yang biasa disebut pariwisata cerdas. Sebagai konsep inti pariwisata cerdas, informasi pariwisata layanan merupakan premis penting untuk konsumsi informasi pariwisata, artinya pemberian informasi memimpin dalam konsumsi informasi wisatawan, dan makro peningkatan konsumsi informasi lingkungan meningkatkan pasokan layanan informasi pariwisata. (Smart Tourism) (Li, 2016)

Smart Tourism atau pariwisata cerdas adalah destinasi wisata inovatif yang dibangun di atas infrastuktur berteknologi canggih yang menjamin pembangunan berkelanjutan area wisata, dapat diakses semua orang, memfasilitasi interaksi dan integrasi pengunjung dengan lingkungan sekitarnya, meningkatkan kualitas pengalaman di destinasi tersebut, dan meningkatkan kualitas hidup masyarakatnya. (Haas, 2019)

Pariwisata cerdas berada di antara teknologi destinasi wisata dan teknologi yang dimiliki wisatawan. Teknologi destinasi wisata adalah big data, robotika, analitika data, kecerdasan buatan, biometric. Informasi data tersebut berbentuk data instan yang masif berisi data demografik, data sumber, data manajemen dan data marketing wisatawan. Dengan adanya analisis dan proses big data penyedia wisata dapat menambahkan hubungan yang 
bernilai ekonomis dan meningkatkan usaha pariwisata juga dapat melayani wisatawan lebih baik.

Salah satu bentuk pariwisata cerdas aplikatif yang sedang berkembang di masyarakat dunia adalah platform bisnis ekonomi berbagi. Platform ini memanfaatkan teknologi informasi untuk memberdayakan pengguna untuk berbagi dan meminjam barang atau jasa yang kurang dimanfaatkan. Ekonomi berbagi di bidang jasa meliputi, transportasi, akomodasi juga keuangan. Salah satu yang paling mencolok dari ekonomi berbagi adalah Airbnb, situs jaringan rental akomodasi untuk liburan. Airbnb sendiri mendefinisikan dirinya "Sebuah situs sosial yang menghubungkan orang yang memiliki ruang dan membagikannya untuk orang yang membutuhkan tempat menginap." Perusahaan Airbnb didirikan pada tahun 2008, tumbuh secara eksponensial dalam beberapa tahun terakhir dan sekarang sudah menyewakan lebih dari 1,5 juta properti di 190 negara dan 34.000 kota. Pada akhir tahun 2014, Airbnb mencetak lebih dari 70 juta malam terpesan dalam platformnya.

\section{METODE}

Penelitian ini adalah studi kualitatif dengan metode deskriptif. Data untuk penelitian ini dikumpulkan melalui studi sastra, wawancara dan pengamatan langsung ke objek. Studi literatur ini dilakukan untuk menjadi acuan dan dasar sebagai pra-observasi setelah data yang dikumpulkan melalui wawancara dan observasi langsung ke objek, maka telah divalidasi menggunakan sumber Triangulasi dan dianalisis secara deskriptif oleh penulis.

\section{HASIL DAN PEMBAHASAN}

Konsumen di dalam industri pariwisata yang lebih dikenal dengan wisatawan memperoleh keuntungan yang signifikan dalam skema ekonomi berbagi yang tersedia dikarenakan perjalanan dapat diakses lebih mudah, lebih murah dan kapanpun. Dalam model bisnis ekonomi berbagi, akomodasi berbagi adalah layanan yang paling banyak digunakan karena lebih ekonomis dan kepedulian sosial seperti contoh praktek komunitas dan interaksi sosial (Kim et la, 2017).

Dalam platform ekonomi berbagi Airbnb, masyarakat luas dapat dengan mudah untuk menyewakan kamar dalam rumahnya ataupun properti lain ke dalam platform tersebut dan dapat dijangkau oleh wisatawan secara luas, skema tersebut lebih dikenal dengan istilah peer-to-peer accomodation atau akomodasi dari pengguna akhir ke pengguna akhir. Platform peer-to-peer tersebut mendorong pengguna Airbnb baik wisatawan atau tuan rumah untuk berlibur atau menerima tamu yang sama sekali belum mereka kenal sebelumnya (Richardson, 2015) dan mempersilakan orang asing untuk berbagi tempat tinggal memungkinkan terjadinya resiko juga permasalahan keamanan.

Setiap keluarga tentu memiliki area pribadi dalam rumah yang tidak dapat diakses oleh umum walaupun sebagian kamar lain di rumahnya disewakan secara umum. Area pribadi tersebut biasanya adalah kamar utama pemilik rumah, ruang keluarga inti, area dapur keluarga, dan kamar mandi pribadi. Walaupun berbeda-beda jenis area pribadi tersebut namun tentu ada batasan untuk tamu dapat mengakses setiap bagian rumah tersebut. Hal ini dapat diantisipasi dengan pengaturan awal tuan rumah dalam membuat listing di akun Airbnb tersebut. Tuan rumah dapat memisahkan area yang dapat diakses oleh tamu dan yang hanya bisa digunakan oleh pemilik rumah.

Untuk permasalahan keamanan para tuan rumah di beberapa tempat menyiapkan properti miliknya dilindungi dengan berbagai alat keamanan seperti kunci pintar yang dapat dibuka menggunakan sandi dan kode batang, juga kamera pengawas dengan sensor gerak yang dapat mengirimkan sinyal ke ponsel pintar pemilik jika ada aktivitas mencurigakan. Airbnb sendiri mewajibkan untuk tuan rumahnya memiliki sensor asap dan karbon dioksida untuk keamanan bersama. Hal ini dapat meminimalisasi resiko baik kerusakan dan permasalahan keamanan. Dengan penambahan fasilitas keamanan tersebut juga sekaligus menambah kenyamanan tamu saat menginap di properti milik tuan rumah karena fasilitas keamanan dan kemudahan dalam mengakses properti tersebut.

Namun Airbnb sendiri sudah menyiapkan kebijakan-kebijakan untuk mencegah dan menanggulangi permasalahan keamanan, terutama yang disebabkan oleh wisatawan. Mulai dari ruang virtual untuk menyelesaikan masalah kerusakan dan kehilangan barang sehingga tuan rumah dapat mengajukan ganti rugi untuk barang yang hilang atau rusak kepada wisatawan dengan bukti dokumentasi keadaan asli barang tersebut sebelum dan sesudah kerusakan. Airbnb menyiapkan asuransi terhadap properti tuan rumah nilainya sampai 1 juta dolar Amerika, bagi tuan rumah yang tertimpa kerusakan properti seperti kebakaran, banjir maupun kerusakan lainnya yang disebabkan wisatawan. Dengan jaminan ini diharapkan baik wisatawan dan tuan rumah memiliki rasa aman dalam menjalankan usaha penyewaan akomodasi maupun menginap di akomodasi peer-to-peer. Dengan rasa aman tersebut timbul keyakinan untuk menyewa ataupun menggunakan fasilitas akomodasi tersebut.

\section{Big Data dan Pemasaran Bertarget}

Dalam sejarah pengumpulan data berkualitas tinggi dalam penyewaan akomodasi telah terbukti sangat sulit untuk diperoleh. Namun dengan sumber baru dari Big Data dalam pasar penyewaan membuat data tentang segmentasi pasar lebih mudah untuk didapatkan dan dipelajari. Peneliti dapat meningkatkan jangka waktu lebih jauh dalam mengukur aliran harga dari rumah-rumah hanya dengan menyurvei satu kontrak jual beli rumah, daripada survey tradisional yang mendatangi semua penyewa (Glaeser and Gyorko, 2007). Data tersebut sangat berguna untuk menjadi panduan dalam mengambil keputusan 
pengusaha maupun kebijakan pemerintah dalam meningkatkan perekonomian masyarakat.

Big Data juga digunakan untuk memberikan informasi yang diperlukan calon penyewa akomodasi tersebut secara spesifik dan personal mengikuti sejarah tingkah laku dan preferensi wisatawan tersebut. Sebagai contoh preferensi wisatawan yang sering mencari informasi tentang rumah pantai akan mendapatkan iklan maupun penawaran rumah pantai di bagian paling atas dari pencarian. Begitu pula alternatif pilihan-pilihan akomodasi di bagian bawah halaman situs adalah pilihan-pilihan sesuai preferensi wisatawan tersebut.

Dari platform Airbnb yang memudahkan pemasaran, proses transaksi bagi kedua belah pihak baik penyedia dan pengguna layanan tersebut, tentu terjadi kolaborasi dan pertumbuhan ekonomi. Airbnb baru saja melaporkan perkiraan valuasi sebesar \$24 miliar (US), hal ini melebihi kapitalisasi pasar rantai hotel global seperti Marriott International. (Winkler dan MacMillan, 2015).

\section{SIMPULAN}

Perkembangan jaman di era digital 4.0 melahirkan banyak pekerjaan dan peluang baru, salah satunya adalah penggunaan rumah masyarakat untuk penyewaan akomodasi ekonomi berbagi. Dampak positif dari hal tersebut adalah peningkatan ekonomi masyarakat di sekitar tempat akomodasi berada, baik dari tuan rumah sendiri juga dengan masyarakat baik dari lowongan pekerjaan juga penyedia makanan, dan sebagainya.

Namun tidak dapat dipungkiri perubahan skema bisnis menimbulkan banyak keraguan baik dari tuan rumah maupun wisatawan terutang persoalan keamanan. Dalam hal ini tuan rumah dapat proaktif dengan menyediakan fasilitas keamanan seperti kunci pintar, kamera pengaman, pendeteksi asap dan lain sebagainya. Di sisi lain pihak platform memberikan jaminan sampai 1 juta dolar Amerika, untuk memberikan rasa aman bagi tuan rumah untuk menyewakan rumahnya.

Dengan bantuan Big Data, platform memberikan informasi spesifik dan personal kepada calon pembeli jasa akomodasi sesuai dengan preferensi masing-masing sehingga membantu mempercepat keputusan pembelian wisatawan. Big Data juga dapat membantu untuk penelitian tentang harga pasar properti dan memberikan gambaran untuk membantu pembuatan keputusan pengusaha dan kebijakan pemerintah.

\section{DAFTAR PUSTAKA}

Pustaka yang berupa majalah/jurnal ilmiah:

Aas, C., Ladkin, A.(2015b), Stakeholder Collaboration and Heritage Management. Annals of Tourism Research, 32(1), 22-48. etrieved from https://www.researchgate.net/

Belanche, D., Casal_o, L. V., \& Flavi_an, C. (2017). Understanding the cognitive, affective and evaluative components of social urban identity: Determinants, measurement, and practical consequences. Journal of Environmental Psychology, 50, 138e153.

Chapin, F. S., III, \& Knapp, C. N. (2015). Sense of place: A process for identifying and negotiating potentially contested visions of sustainability. Environmental Science \& Policy, 53, 38e 46.

Fladmark, J.M., Habgood, J. (1994). Cultural Tourism: Papers Presented at the Robert Gordon University Heritage Convention, 1994. London: Donhead Publishing.

Glaeser, E. L. and Gyourko, J. (2007). Arbitrage in housing markets, NBER Working

$\begin{array}{lll}\text { Paper No. 13704, } & \text { No. }\end{array}$ http://www.nber.org/papers/w13704.

Haas, Frank. Pariwisata Cerdas dan Berkelanjutan untuk Jawa Barat. East West Center, Smart Cities. 2019

Hay, R. (1998). Sense of place in developmental context. Journal of Environmental Psychology, $18,5 \mathrm{e} 29$.

Hewison, R. (1998). Revising and Implementing the Marketing Concept as it Applies to Tourism. Tourism Management, 11(3), pp. 195-205.

Lewicka, M. (2011). Place attachment: How far have we come in the last 40 years? Journal of Environmental Psychology, 31(3), 207e230.

Li, M. M., Wu, B. H., \& Cai, L. P. (2008). Tourism development of world heritage sites in China: A geographic perspective. Tourism Management, 29(2), 308e319

Li, Y.; Hu, C.; Huang, C.; Duan, L. The concept of smart tourism in the context of tourism information services. Tour. Manag. 2017, 58, 293-300

Loukaitou-Sederis, A. (1995). Urban form and social context: Cultural differentiation in the use of urban parks. Journal of Planning Education and Research, 14, 89e107

Manzo, L. C., \& Perkins, D. D. (2006). Finding common Ground: The importance of place attachment to community participation and planning. Journal of Planning Literature, 20(4), $335 \mathrm{e} 350$ 
Piro G, Cianci I, Grieco L, Boggia G, Camarda P. (2014b). Information centric services in Smart Cities. Journal of Systems and Software, 88(1), 169-188. Retrieved from https://www.sciencedirect.com/

Pretty, G. H., Chipuer, H. M., \& Bramston, P. (2003). Sense of place amongst adolescents and adults in two rural Australian towns: The discriminating features of place attachment, sense of community and place dependence in relation to place identity. Journal of Environmental Psychology, 23(3), 273e287

Ramli, R. (2015, Desember). Sektor Pariwisata Paling Murah. Kompas, p. 1. Jakarta. Retrieved from kompas.com

Tan, S. (2018b) Sense of place and sustainbility of intagible cultural heritage - The case of George Town and Melaka. Tourism Management 67, 376-387 Retrieved from www.elsevier.com/locate/tourman

Wegmann, J. (2017b) Taming Airbnb: Towardn guiding principles for local regulation of urban vacation retal based on empirical result from five US cities. Land Use Policy 69, 494-501 Retrieved from www.elsevier.com/locate/landusepol

Winkler, R., MacMillan, D., 2015. The Secret Math of Airbnb's \$24 Billion Valuation: Home-rental Site's Revenue Projected to Top More than $\$ 900$ Million. Wall Street Journal (June 17).
Pustaka yang berupa judul buku:

Azwar, S. (2007). Metode penelitian. Yogyakarta: Pustaka Pelajar.

Lunsford, A., \& Ede, L. (2009). Child education: Perspective on teaching activities. Carbondale: Illinois University Press.

Willig, C. (2008). Introducing qualitative research in psychology: adventures in theory and method. (2nd ed.). London: McGraw-Hill Open University Press

\section{Pustaka yang berupa Prosiding Seminar:}

Desiningrum, D. R. (2011). Future time perspective, goal orientation, and subjective well being in elderly. The Padjadjaran International Conference on Psychology (pp.17-23). Bandung, Indonesia: Faculty of Psychology, Padjadjaran University.

\section{Pustaka yang berupa disertasi/tesis/skripsi:}

Pratama, A. G. (2009). Kontribusi kesejahtera-an subjektif pada religiusitas Islam, persepsi tentang penyakit, dan perilaku menjaga kesehatan diri dalam model perilaku memelihara kesehatan: Suatu upaya menemukan model perilaku meme-lihara kesehatan dengan taraf keccokan optimal pada penderita HIV+. Disertasi. Program Pascasarjana Universitas Padjadjaran Bandung.

\section{Pustaka yang berupa Handbook:}

Albarracin, Johnson, \& Zanna. (2005). The handbook of attitudes. New Jersey: Erlbaum.

American Psychological Association. (2010). Publication manual of the American Psychological Association. Sixth edition. Washington D.C.: American Psychological Association 